\title{
Developing Supplementary Extensive Reading Materials Based on Berau Folklore by Using Flipbook Media
}

\author{
Yuli Puji Astutik, Surti Milarisa. \\ \{Billie.imoetz@gmail.com¹, milarisa78@gmail.com\}
}

\begin{abstract}
Sekolah Tinggi Ilmu Tarbiyah Muhammadiyah Tanjung Redeb, Jl. Jend. Sudirman Tanjung Redeb Berau Kalimantan Timur ${ }^{1}$, Universitas Muhammadiyah Berau, Jl. Dr, Murjani II Tanjung Redeb, Berau, Kalimantan Timur².
\end{abstract}

\begin{abstract}
Reading is a complex process that requires a complex set of skills. To gain an understanding of reading, someone needs to go through a fairly long process. Therefore, reading materials should meet several important features that can support teaching learning activities. Based on the result of needs analysis, the writer found that there was no easy and interesting extensive reading material for university students in Berau Regency which can be used as teaching tool. Concerning this problem, a set of supplementary reading material for students needed to be developed. This material consists of several English reading texts based on Berau folklore. The researchers applied several procedures in this research: conducting needs analysis, developing supplementary materials, conducting expert validation, revising the materials, trying out the materials, and revising the materials. The researchers collected the data by using quistionaires, interview, analyzing the syllabus and checklist. The product of this research is four units of supplementary extensive reading materials.
\end{abstract}

Keywords: Supplementary Extensive Reading Material, Berau Folklore, Flipbook Media.

\section{Introduction}

Reading is important aspect of human life. It is a way of communication which can turn writing into information or meaning. Almost all of the knowledge that exists in human civilization can be accessed through reading. This is in accordance with the opinion of Grabe (2009:5) Citizens of modern societies must be good readers to be successful. Reading skills do not guarantee success for anyone, but success is much harder to come by without being a skilled reader. Milarisa (2019: 14-20) stated that reading is one of the four main important 
skills. Reading will help students to get easy in interpreting a language. Based on those opinions, the authors conclude that reading must be mastered by all mankind in order to be able to master science and all things in this world because being a skilled reader is one of the keys to success in learning and the keys to success in life.

Reading is a cognitive process. It refers to the abilities to gain meaning and knowledge from experience and information. Cognition is more than just learning information. It is the ability to think about new information process and speak about it and apply it to other previously acquired information. Grabe (2009:5) argued that there are several central role of cognition in reading comprehension. 1) Implicit and Explicit Learning, 2) Frequency, associative learning, co-occurence, and emergence, 3) Attention, noticing, and consciousness, 4) Inferencing, 5). The role of context in L2 Reading, 6). The role of background knowledge in L2 Reading. The theory of Grabe above shows that reading is a complex process which needs an extra effort to master.

Reading not only requires efficient and congruous use of many process such as attention, perception, and comprehension, but also covers both cognitive and meta-cognitive process (Block \& Pressley, 2002, p. 3; Grabe and Stoller, 2002, pp.4-10; Kem, 1989, p.135). It proves that reading is not a simple task that can be mastered in a short time but it need a fairly long process to be a better skilled reader.

People have different purposes for reading. Some people read for the shake of getting information, knowledge, facts, which are stated in the written text, but some others read for pleasure and enjoyment. Previous studies proved that how a person reading purpose and a different task, will perform differently on the latter task (cf Alderson, 2000; Horiba, 2000; Swanborn \& de Glopper, 2001). There are also range of studies in educational psychology and discourse processing that demonstrate significant differencess in comprehension processing as a result of different purposes for reading (Linderholm \& van den Broek, 2002; Lorch \& van den Broek, 1997)

Gurses \& Adiguzel (2013) The core of effective teaching is highly based on understanding the nature of learning. Thus figuring out the components included in an effective reading process, the behaviors displayed by an effective reader during this process, and how individuals learn a foreign language plays a crucial role for teaching reading in a foreign language. So, in teaching reading, the way how the students read is not the major target, but how the way to make them a skilled reader who can comprehend the text effectively is highly needed. It requires some complex cognitive and metacognitive process.

In countries around the world, school systems require students to learn English for access to information and for the eventual ability to complete economically and professionaly. For good and for bad, this situation reflects a reality of the early twenty-first century (Crystal, 1995; McGroarty, 2006). It must be understood that the success or failure of education system is interelated with the supporting aspects and facilities in education itself. It can be about the school facilities, school devices, technology, and also human resourches.

Smaldino, et al (2007) asserted that technology plays an important role in the education of students who have specificities. Technology and media that are tailored and speciffically designed can contribute to learning that is carried out traditionally without using multimedia. Spector \& Anderson (2000) also state "we support this trend and believe, along with many others, that technology can be used in distributed learning environments to support learning in and about complex systems." 
Tomei (2005) empasizes that "Classrooms and schools are the most successful use of best practices strategies for teaching and learning, including technology. Teachers who serve not only as dispensers of knowledge (the proverbial "sage on the stage") but also alongside their facilitators (the "guide by the side") from true learning communities that are supported by technology-based resources that become part and parcel of their curriculum.

What is the gap in the literature that is addressed by this study?

Also, mention the findings-based argument of the paper here.

\section{Related Literature}

\subsection{Extensive Reading}

Aims of Extensive Reading not only to provide entertainment for students as they read, but also to expand the students' understanding of the language so that their skills will develop. "...Reading for pleasure (extensive reading) is the major source of our reading competence, our vocabulary and our ability to handle complex grammatical constructions" (Krashen in Miculecky and Linda, 2007). Another opinion on the benefits of extensive reading is expresses by Day and Bradford, also in Miculeckly and Linda (2007) "Extensive reading may play role in developing the capacity for critical thinking that is so important for success in higher education." By getting the students accustomed to extensive reading, we can expect that they will be able to solve relevant to the students' lives helps them to understand the passages as whole

\subsection{Flipbook}

According to Haryanti \& Saputro (2016) Flipbook Maker is a software that has the function to open each page like a book. Kvisoft Flipbook allows users to convert Word, Exel, PPT, PDF to flash flipbook with compelling page turning effects. Flipbook is one of the presentation media that is able to create impressive and interesting digital editions such as product catalogs, business brochures, magazines, ebooks, wedding books, greeting cards, annual reports, promotional leaflet, photo books etc. To share online and offline. Flipbook

Astutik (2017) Flipbook has many advantages and can be used as an alternative technology-based information delivery media. This tool allows users to present the information in an attractive way which can be displayed on a large canvas. Based on those theories it can be summarized that Flipbook is an eye cathing tool to display e-book, emagazine, e-card, photo book etc which can be accessed through online and offline devices such as computer, laptop, tab, or even mobile phone.

\subsection{Previous Studies on Supplementary Reading Materials}


Azizah \& Sugirin (2019) found that environment-based supplementary reading materials is needed to be developed to cover students' need about suitable material which were consisting of new vocabulary, a comic, a main text, and exercise.

Thakur (2015) suggests that authentic material is needed for the purposes of language teaching because the use of authentic materials has a definite place in language learning in ESL/EFL context.

Abbasi, Z. et.all (2015) found that Supplementary Materials of Reading Comprehension may help the learners to enhance their independent English language learning and improve their reading comprehension.

Mokhtari \& Talebinezad (2014) from their research findings showed that supplementary reading has positive effect on developing conceptual fluency of L2 Learners.

Febriani (2015) argued that it is needed to develop supplementary reading materials that is suitable to students need and it is expected that the supplementary reading material can guide students to learn specific subject through the Engliah reading material.

Restate the gap in the literature that is addressed by this study.

\section{Methodology}

Tuckman (1978) explained that research is used to describe a number of similar and often overlapping activities involving a search for information. The appropriate design to use in this research was Educational Research and Development (RnD). According to Borg and Gall (2003) the objective of educational research and development is a finished product that can be used effectively in an educational program. Besides, Research and Development is a process to develop, validate and testing the effectiveness of certain products Sugiyono (2010). From those theories, the writer can conclude that R\&D research is a process or steps to develop a new product or to develop and existing product to be used in education.

The writers elaborated the ADDIE model approach proposed by Molenda with the steps in Borg \& Gall Process. ADDIE model starts from analysys, design, development, implementation and evaluation. It can be explained respectively in the following parts:

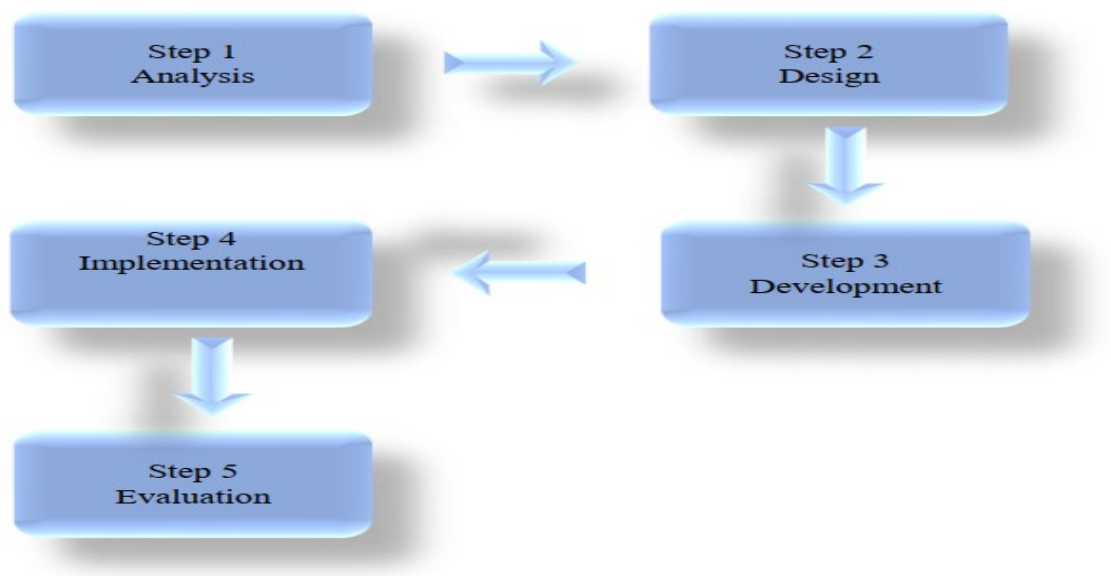




\section{Fig. 1 Step of ADDIE Model}

The research design of this study followed the educational Research and Development (R\&D) methodology outlined by Borg and Gall (2003). The seven steps: research analysis, needs assessment and proof of the concepts; product planning and design; preliminary product development; preliminary testing; product revision; main field testing; and the final product revision and dissemination.

\subsection{Research Analysis, Needs Assessment and Proof of the Concepts}

This step was carried out for several reasons. The first reason was to gain the information about the lecturers and students need for the materials, the second was for avoiding too easy or hard material which may cause boredom and frustration for the students. The third was for avoiding incomplete, redundant, or innacurate content of the materials.

There were four subjects involved in this steps. The first subject were students of STIT Muhammadiyah Tanjung Redeb which consist of 30 students. The second subjects were students of University of Muhammadiyah Berau which consist of 70 students.

\subsection{Product Planning and Design}

The product planning and design was done after the needs analysis process. It was based on the result of the quistionaire of the students and lecturer. From the data gathered, the researcher then started to design the draft/research planning which consisted of four topics, vocabulary building lists, key to pronunciation, and exercises. These documents were used as guide to develop the preliminary product.

\subsection{Preliminary Product}

In this step, the reasearcher created the prototype of the product based on the literature review, handbook observations, and expert's feedback. In the process of the development material the researcher also did expert validation. Because suggestions and criticisms from the experts are needed in order to make a better final product later. It is expected that this development research would reach the goal that was providing the acceptable $\&$ appropriate supplementary material of extensive reading.

\subsection{Preliminary Field Test}

The prototype for creating the supplementary extensive reading material book was evaluated through a preliminary field test. Three experts were asked to review and evaluate the prototype. The preliminary field testers were drawn from a proof of the experts who met at least one of the following criteria: 1. Recognized as an expert in Extensive English teaching for at least ten years, 2. Recognized as an expert of translation study, 3. Recognized as an expert in developing educational media, 4. Have the doctoral degree as their educational background. 
The experts which met the criteria in preliminary field test included Dr. Ahmad Bahruddin M.Pd, Dr. Sugeng Hariyanto, M. Pd, and the last validator was Dr. Johanes Radjaban, M.Pd. After selecting the expert validators, the researcher then asked them to validate the product. In this step, validation meant confirmation of the product by the expert. It was because the product as the result of the development stage was still a prototype or a proposed design so the expert's opinion would be very important to be considered for developing the better final product. The purpose of this evaluation was to measure the course's effectiveness and locate the opportunities to improve the performance of the product. The expert verification was for determining whether the material was appropriately designed and developed or not. After having correction and feedback from the expert, the researcher revises the prototype based on it.

\subsection{Product Revision}

This stage involves validation based on experts in preliminary field test. The revision of the product was based on the feedback and comments from the experts so that it could be able to achieve the optimal result in teaching extensive reading to the real subject of the study. The researcher did the process for having the validation in several times. In the first product revision, the experts gave some revision notes to be followed back by the researcher. After revising the product then the researcher asked the experts for their comments on the revised product. Finally the researchers got the validation from those experts. It meant the product had fulfilled the criterion of the applicable product and can be tested to the students.

\subsection{Main Field Test}

In main field test, the writer selected the subjects of the study purposively or based on the porpose. After having the product revision, and developing the product, the researcher gave the limited try-out to the students in order to gain the information about what actually occurred in the classroom application of the developed material. The subjects of the limited try-out were students of English Department of STIT Muhammadiyah Tanjung Redeb, and students of University of Muhammadiyah Berau were involved as the subject of the limited try-out. There were 100 students selected as the subjects of the main field test.

\subsection{Final Product Revision and Dissemination}

After application of the main field test, the researcher did not do the product revision as there was no additional feedback from the students related to the product that had been tested to them.

The researcher also did not do the disemination process right after the research process because of the limited time and budget restrain of the research.

\subsection{Subject and Data of the Study}

There were two kinds of subjects and datas used in this study. They were the subjects involved in the needs analysis process and subjects in the development of the material. Besides, there 
were two types of the data which were used in this study. They were (a) the data gathered during the research analysis, needs assesment and proof of the concept and (b) the data given in preliminary field test.

\subsubsection{Subjects and Datas on Research Analysis, Needs Assessment and Proof of the Concept}

The data gathered from the students in needs analysis process were their needs, interests, and expectations related to pronunciation teaching and learning. Besides, the data obtained from the lecturer were his expectations to the material of extensive reading course. Then, the second data is used to determine the applicability of the material for the students.

\subsubsection{Subjects and Datas on Preliminary Field Test}

In the development of the material, the researchers asked the experts for their feedback and comments for the revision purpose. In this study there were three experts involved in preliminary field test. The validation of the product covered several aspects such as design, topics, organization, content, coverage, language; instruction, sand exercise.

\subsection{Techniques of Data Collection}

To collect the data from the needs analysis, the researcher collected them through the questionnaires. It was used to investigate about the needs, interest and expectations of the students during the teaching of extensive reading. The questionnaire for students covered 8 criteria.

Besides, for the main field test, the researcher collected them through the students' checklist about the appropriateness of the developed material with their needs. The checklists were distributed to the students when the researcher gave them the try out of the developed product.

\section{Findings and Discussions}

\subsection{Result of Needs Analysis}

The result of need assessment from students' checklist related to the previous book of extensive reading.

Table 1. The weakness criteria of the existing extensive reading book

\begin{tabular}{ll}
\hline No & Weaknesses' criteria \\
\hline 1 & $\begin{array}{l}\text { The previous extensive reading book was really difficult to find and } \\
\text { difficult to comprehend as most of them are from abroad and written } \\
\text { by native English authors. }\end{array}$ \\
\hline 2 & Most of previous extensive reading books from the lectures were not
\end{tabular}


equipped by some exercises to help the students to comprehend the texts they read

3 Almost all the material in the existing extensive reading books were not supported by the value of students' cultures so both the students and the lecturers suggested to develop supplementary extensive reading materials which consist of Berau Folklore as the local wisdom.

4 The previous extensive reading books had less activities which encourage students' motivation in learning English extensive reading.

5 The existing extensive reading books were not completed by some vocabulary building words which can help the students to comprehend the texts easily.

6 The previous extensive reading books didn't meet the students' need about how to utter difficult vocabularies by clear symbol of English sounds.

Table 2. The result of students' quistionaire on needs analysis process

\begin{tabular}{|c|c|c|c|c|}
\hline No & Indicators & Students' Response & $\begin{array}{l}\text { Numbe } \\
r \quad \text { of } \\
\text { student } \\
s\end{array}$ & $\begin{array}{l}\text { Perce } \\
\text { ntage } \\
(\%)\end{array}$ \\
\hline 1 & $\begin{array}{l}\text { Students interest in } \\
\text { learning English. }\end{array}$ & $\begin{array}{l}\text { - Really interested } \\
\text { - Interested } \\
\text { - Less interested } \\
\text { - Not interested }\end{array}$ & $\begin{array}{l}70 \\
20 \\
10 \\
0\end{array}$ & $\begin{array}{l}70,0 \\
20,0 \\
10,0 \\
0,0\end{array}$ \\
\hline 2 & $\begin{array}{lr}\text { Students' } & \text { opinion about } \\
\text { learning } & \text { English } \\
\text { extensive reading. }\end{array}$ & $\begin{array}{l}\text { - Really important } \\
\text { - Important } \\
\text { - Less important } \\
\text { - Not important }\end{array}$ & $\begin{array}{l}85 \\
10 \\
5 \\
0\end{array}$ & $\begin{array}{l}85,0 \\
10,0 \\
5,0 \\
0,0\end{array}$ \\
\hline 3 & $\begin{array}{l}\text { Students' interest in } \\
\text { learning } \\
\text { extensive reading. }\end{array}$ & $\begin{array}{l}\text { - Really interested } \\
\text { - Interested } \\
\text { - Less interested } \\
\text { - Not interested }\end{array}$ & $\begin{array}{l}71 \\
29 \\
0 \\
0\end{array}$ & $\begin{array}{l}71,0 \\
29,0 \\
0,0 \\
0,0\end{array}$ \\
\hline 4 & $\begin{array}{lr}\text { Students' } & \text { familiarity of } \\
\text { learning } & \text { English } \\
\text { folklore. } & \end{array}$ & $\begin{array}{l}\text { - Really familiar } \\
\text { - Familiar } \\
\text { - Less familiar } \\
\text { - Not familiar }\end{array}$ & $\begin{array}{l}21 \\
39 \\
48 \\
2\end{array}$ & $\begin{array}{l}21,0 \\
39,0 \\
48,0 \\
2.0\end{array}$ \\
\hline 5 & $\begin{array}{l}\text { Students' opinion about } \\
\text { the need of extensive } \\
\text { reading material based } \\
\text { on Berau folklore as } \\
\text { their local wisdom. }\end{array}$ & $\begin{array}{l}\text { - Really needed } \\
\text { - Needed } \\
\text { - Less needed } \\
\text { - Not needed }\end{array}$ & $\begin{array}{l}88 \\
12 \\
0 \\
0\end{array}$ & $\begin{array}{l}88,0 \\
12,0 \\
0,0 \\
0,0\end{array}$ \\
\hline
\end{tabular}


6 Students' opinion about - Really difficult to get $91 \quad 91,0$ the unavailability of - Difficult to get 990 extensive reading $\bullet$ Easy to get 00 material based on berau $\bullet$ Very easy to get $\quad 0 \quad 0,0$ folklore

7 Students' opinion about $\bullet$ Really needed $\quad 89 \quad 89,0$ the need of extensive • Needed $11 \quad 11,0$ reading material $\bullet$ Less needed 000 development based on $\bullet$ Not needed 00 Berau folklore as their local wisdom

$8 \quad$ Students' opinion about $\bullet$ Really needed $\quad 80 \quad 80,0$ the illustration on the - Needed $20 \quad 20,0$ extensive reading $\bullet$ Less needed 000 materials development $\quad$ Not needed $\quad 0 \quad 0,0$ 


\subsection{Interview with the Lecturers}

The lecturers explained that in the teaching and learning of extensive reading, they usually get some downloadable and printable story books from the internet as it was difficult to find bookstores in Berau Regency. Some bookstores around the Regency only sell some textbooks of elementary school, junior high school and also senior high school.

The lecturers suggested that the topics on the extensive reading books should be equiped with some exercises so that it could facilitate the students to deepen their understanding about the materials. They also stated that the extensive reading book need to be facilitated with key to pronunciation of difficult words so that the students can learn not only how to comprehend the text but also how to utter the difficult vocabularies easily and correctly. Besides, they also suggested that to make the students to have better understanding, the material developed should also be completed by some exercises about synonym and antonym.

\subsection{Data Collection from Syllabus}

The result of the data collection from the syllabus consisted of standard competence, and basic competence based on extensive reading subject as the fundamental in arranging the developed material in this research.

\subsection{Result of Developed Materials}

The draft of the supplementary material development focused on extensive reading based on Berau folklore as the lokal wisdom. It covered four topics of disscussions. Every topic was completed by the key to pronunciation of difficult words, exercises on synonyms and antonyms, multiple choice exercises and also essays related to the text comprehension. Those four topics were about local folklore of Berau. The researchers took those topics under some considerations that there were no extensive reading books in Berau Regency, it was difficult to find any books about those folklores even in Bahasa Indonesia, and the topics was chosen to meet the students' need about the easiest material of extensive reading related to their local wisdom.

\subsection{The Result of Expert Validation}

After the draft of supplementary extensive reading material developed has already done the researchers did the validation of the product to some experts. They chosed three validators which meet the criteria of the material developed. 
The first validator was Mr. Dr. Ahmad Bahruddin as the expert of media. He focused on his field about the flipbook media which was used as the tool to display the electronic version of the supplementary extensive reading material. For the evaluation on the book cover and display of the page paper, he suggested not to use bright and colorful color to avoid breaking the convinience of eyes when reading in front of the laptop screen, tab, or other devices.

The second validator was Mr. Dr. Sugeng Haryanto as the expert on translation. He fixed some minor errors on language structures and did some revisions to the material developed. He said that the overal product was good and can be used as the reference in teaching extensive reading to university students.

The last validator was Mr. Dr. Johanes Radjaban as the expert of the content of material developed. He said that the product was very good to be used as one of the reference of the students who wants to expand their knowledge and understanding about extensive reading while learning about their own local folklores. He also added some suggestions about changing the color of the material display on some pages by using soft colors.

\subsection{Revision of the Product}

After getting some criticisms and suggestions from the expert validators, the researchers then did material revision to fix some errors on the product developed. The researchers also redesigned the display of the book cover, and page of the book color which were suggested by the validators. After the product has already meet the suggestion of the validators and has already improved, the researchers then did the next step to try out the product to the students of two universities.

\subsection{Result of the Try-Out}

In order to obtain the criteria of the empirical validity of the material developed, the researchers conducted try out to the students of two universities. They were students of Sekolah Tinggi Ilmu Tarbiyah Muhammadiyah Tanjung Redeb and students of University of Muhammadiyah Berau. The data of the try out were gathered from the students' quistionaires in order to improve the product and to investigate the approppriatteness of the product. The quistionaires of the try out focused on twelve points which represent students' opinion related to the supplementary extensive reading material developed. The result of students' try out can be seen as follows:

Table 3 Result of Students' Try out on Main Field Test

\begin{tabular}{llllll}
\hline No & Criteria & \multicolumn{4}{l}{ Percentage (\%) } \\
\cline { 3 - 5 } & & SA & A & D & SD \\
\hline 1 & The explanation in the product is easy to & 75.5 & 25.5 & 0 & 0 \\
\hline
\end{tabular}




\begin{tabular}{|c|c|c|c|c|c|}
\hline & nd. & & & & \\
\hline 2 & $\begin{array}{l}\text { The exercises in the product help me } \\
\text { understand the material. }\end{array}$ & 75.5 & 25.5 & 0 & 0 \\
\hline 3 & $\begin{array}{l}\text { The picture and illustration used in the } \\
\text { product is attractive. }\end{array}$ & 58.0 & 42.0 & 0 & 0 \\
\hline 4 & $\begin{array}{l}\text { The option of the word font is } \\
\text { approppriate with the content of the } \\
\text { product. }\end{array}$ & 85.0 & 15.0 & 0 & 0 \\
\hline 5 & $\begin{array}{l}\text { The examples give me clear understanding } \\
\text { about the materials. }\end{array}$ & 80.0 & 20.0 & 0 & 0 \\
\hline 6 & $\begin{array}{l}\text { All the units in the product are easy to } \\
\text { comprehend. }\end{array}$ & 85.0 & 15.0 & 0 & 0 \\
\hline 7 & $\begin{array}{l}\text { The media is suitable for teaching } \\
\text { extensive reading. }\end{array}$ & 65.0 & 35.0 & 0 & 0 \\
\hline 8 & The cover is attractive. & 64.0 & 36.0 & 0 & 0 \\
\hline 9 & The stories in the product is authentic. & 71.0 & 29.0 & 0 & 0 \\
\hline 10 & $\begin{array}{l}\text { The list of vocabularies help me expanding } \\
\text { my vocabulary knowledge. }\end{array}$ & 53.0 & 47.0 & 0 & 0 \\
\hline 11 & $\begin{array}{l}\text { The stories help me know about berau } \\
\text { folklores. }\end{array}$ & 51.0 & 49.0 & 0 & 0 \\
\hline 12 & $\begin{array}{l}\text { The supplementary extensive reading } \\
\text { materials is urgently needed for me as a } \\
\text { student of university. }\end{array}$ & 62.0 & 38.0 & 0 & 0 \\
\hline
\end{tabular}


Based on the result of the students' try out above it can be seen that almost all the students answered "strongly agree" and the rest of them answered "agree" to all of the criteria on the checklists.

\subsection{Revision from Try-Out}

As the result of the students' try-out showed that there were no students who answered disagree and strongly disagree on the checklist, so the researchers didn't do final revision about the developed materials

\subsection{Final Product}

After all the procedures has been passed, the developed supplementary extensive reading material has already been completed. The final prooduct of this research wae in the printed version and ebook version. The electronic version of this book can be accessed on computer device, tab, mobile phone or other devices.

This supplementary extensive reading materials was developed based on students' need and preference and also based on the lecturers' suggestions. This product was arranged based on the standard competence and basic competence of extensive reading course syllabus. This product also facilitated with an eye catching authentic pictures which were created by the researchers. The electronic version of this book also completed by Dayak music as the sound background to make it more interesting and to avoid boredom when the students access it through their devices.

This book is not only facilitated with some interesting features but also facilitated with some exercises to make the students easier in comprehending the text of this book. This book also equiped by key of pronunciation with some phonemic symbols so that the students could also practice to pronounce some difficult words on the list of vocabularies.

The final product display can be seen on figure 2 .

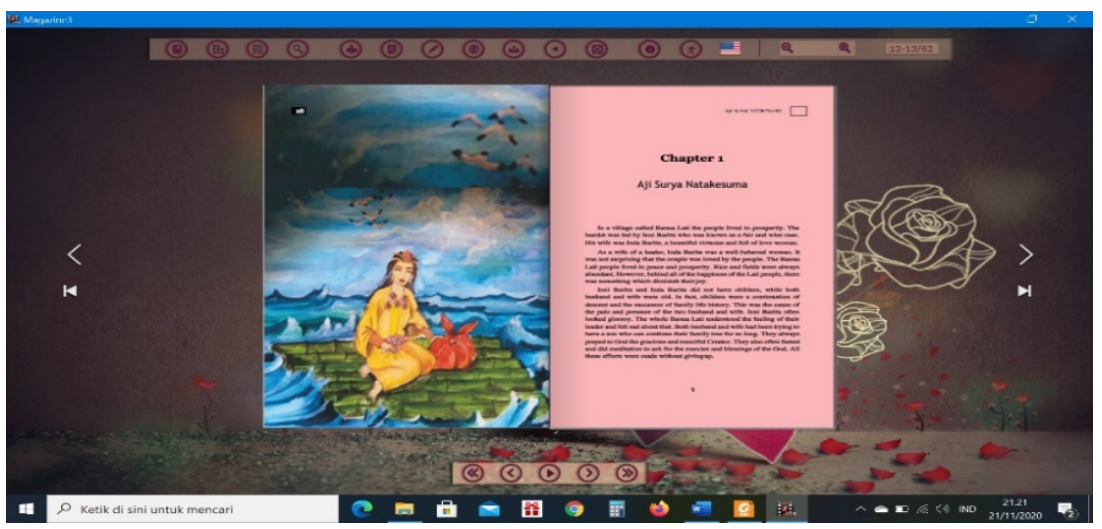

Fig. 2 The final product 


\section{Conclussion}

The result of the developed materials in this research was supplementary extensive reading materials which which can be used as one of references to cover the unavailability of extensive reading material in Berau Regency. This product also aimed to familiarize the culture of Berau through the folklores to the students of Berau partially and to the students outside Berau generally.

This product can also be accessed in printed and electronic versions. The electronic version of this book can be accessed through computer device, laptop, tab, mobile phone, or other devices.

What's the weakness/limitation of the study?

\section{References}

[1] Abbasi, Z et.all The Effect of Supplementary Materials on Reading Comprehension Improvement of Iranian Female High School EFL Learners Based on Gaj and Khate Sefid Text Books. ALLS. 20015; Vol. 6: No. 4

[2] Alderson, J.C. Assessing Reading. New York: Cambridge University Press; 2000. p.

[3] Astutik, Y.P. The Influence of Flipbook Media (Printed vs. Displayed) to Students Reading Comprehension Achievement at STIT.M Berau. ASSEHR. 2018 Vol. 188.

[4] Azizah, M.D \& Sugirin (2019) Environment-Based Supplementary Reading Materials for Junior High School Students. JISE. 2019; Vol 8: No. 1

[5] Block, C.C., \& Pressley, M. (2002) Introduction. In C. C. Block \& M. Pressley (Eds.). Comprehension Instruction: Research-Based Best Practices. New York: The Guildford Press; 2002 pp. [1-7]

[6] Crystal, D. The Cambridge Encyclopedia of Language (2nd Ed.). New York: Cambridge University Press, 1995.

[7] Febriani, H. Developing Supplementary Reading Material for Islamic Learners of MAN 03 Malang Based on Genre Based Approach. CLIJLLT. 2015; Vol. 2: No.1.

[8] Gay, L.R. Educational Research: Competencies for Analysis and Application. $4^{\text {th }}$ Edition. New York: Macmillan Publishing Company. 1992. 
[9] Grabe, W. Reading in a Second Language Moving from Theory to Practice. New York: Cambridge University Press. 2009. p. 5.

[10] Grabe, W, \& Stoller, F.L. Teaching and Researching Reading. Endinburg: Pearson Education. 2002. p. 291.

[11] Gurses, O.M., \& Adiguzel, C.O. The Effect of Strategy Instruction Based on the Cognitive Academic Language Learning Approach over Reading Comprehension and Strategy Use. JEL. 2013; Vol.2: p.2

[12] Haryanti, F. \& Saputro, A.B. Pengembangan Modul Matematika Berbasis Discovery Learning Berbantuan Flipbook Maker untuk Meningkatkan Kemampuan Pemahaman Konsep Pada Materi Segitiga. http://journal.upgris.ac.id/...php/aksioma/article/view/1422 accessed on April, 052020.

[13] Horiba, Y. Reader control in reading: Effects of language competence, text type, and task. Discourse Process. 2000: p. 223-67.

[14] Kem, R.G. Second language reading strategy instruction: Its effects on comprehension and word inference ability. TMLJ. 1989; Vol 73: p.135-149.

[15] Linderholm, T, \& Broek, V.D.P. The effect of reading purpose and working memory capacity on the processing of expository text. JEP. 2002; Vol. 94: p. 778-84

[16] Lorch, R., \& Broek, V.D.P. Understanding reading comprehension:current and future contributions of cognitive science. C E P. 1997; Vol. 22: pp. 213-46.

[17] McGroarty, M. (Ed.). Lingua Franca Languages. ARAL. 2006;Vol.5: 26.

[18] Milarisa, S. The Effect of Paired Reading Strategy in Students' Reading Achievement. LEJ, 2019; Vol.4: p. 14-20.

[19] Mokhtari, E, \& Talebinezhad, M.R. Using Supplementary Readings (Short Stories) in Increasing the Conceptual Fluency, the Case of Idioms in English. ALLS. 2014; Vol. 5: p.1

[20] Smaldino, S.E, Lowther, D,L, James. D, Instructional Technology and Media for Learning, Canada: Pearson Merril Prentice Hall.

[21] Swanborn, M, \& de Glopper, K. (1999). Incidental word learning while reading: A meta-analysis. RER. 1999; Vol. 69: p. 261-85

[22] Spector, J. M \& Anderson, T.M (eds), Integrated and Holistic Perspectives on Learning, Instruction and Technology: Understanding Complexity” Kluwer: Dordrecht, 2000.

[23] Tomei, A.L. Taxonomy for the Technology Domain, London: Information Science Publishing. 2005 
[24] Thakur, V.S. (2015) Using Supplementary Materials in the Teaching of English: Pedagogic Scope and Applications. English Language Teaching. Vol. 8 No. 12

[25] Tuckman, B.W. Conducting Educational Research, 2nd Edition, New York: Harcourt Brace Jovanovich. 1978. 